WSRC-TR---90-336

DE92 013360

\title{
TECHNICAL STUDIES ON A COMPOSITE GROUNDWATER SAMPLE FROM F- AND H-AREA (U)
}

\author{
WSRC Contact:
}

G. F. Stejskal

Westinghouse Savannah River Company

Savannah River Laboratory

Aiken, South Carolina 29808

This is a technical report

This report was prepared in connection with work done under Contract No. DE-AC09-89SR18035 with the U.S. Department of Energy. By acceptance of this paper, the publisher and/or recipient acknowledges the U.S. Government's right to retain a nonexclusive, royalty-free license in and to any copyright covering this paper, along with the right to reproduce and to authorize others to reproduce all or part of the copyrighted paper.

\section{MASTER}

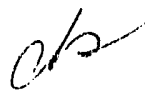

OUSTRIBUTION OF THIS DOCUMEXY IS UNLIMITED 


\section{DISCLAIMER}

This report was prepared as an account of work sponsored by an agency of the United States Government. Neither the United States Government nor any agency thereof, nor any of their employees, makes any warranty, express or implied, or assumes any legal liability or responsibility for the accuracy, completeness, or usefulness of any information, apparatus, product, or process disclosed, or represents that its use would not infringe privately owned rights. Reference herein to any specific commercial product, process, or service by the trade name, trademark, manufacturer, or otherwise, does not necessarily constitute or imply its endorsement, recommendation, or favoring by the United States Government or any agency thereof. The views and opinions of authors expressed herein do not necessarily state or reflect those of the United States Government or any agency thereof. 
WESTINGHOUSE SAVANNAH RIVER COMPANY SAVANNAH RIVER LABORATORY
WSRC-TR-90-336

\author{
Keywords: $F / H$ \\ Seepage Basins, \\ Groundwater Remediation, \\ Surface Treatment, \\ Precipitation, Ion Exchange \\ Retention time: Permanent
}

August 15, 1990

TO: D. L. FISH, 773-A

EROM: J. P. BIBLER, 773-AgPB.

\section{TECHNICAI STUDIES ON A COMPOSITE GROUNDWATRR SAMPIF_FROM F-AND H-AREA (U)}

\section{INTRODUCTION}

A composite sample of groundwater from $F$ - and H-Areas was collected by Waste Management Tech and delivered to the Savannah River Laboratory to use in preliminary experiments that would test three remediation technologies under consideration. The three technologies are $\mathrm{pH}$ adjustment and filtration, decontamination with a strong acid ion exchange resin, and decontamination vith a chelating ion exchange resin.

\section{SUMMARY}

The composite was pH adjusted to $6,7,7.5$, and 8 from 3.3. A smal.1.

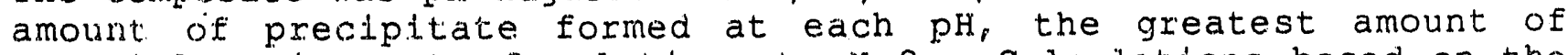
material coming out of solution at $\mathrm{pH} 8$. Calculations based on the mass of precipitate formed per liter at pH 8 show that only 4 grams of solids would be recovered per gallon of composite treated. Of that amount, however, approximately $3.6 \mathrm{~g}$ would be due to incorporated water and only 0.4 grams would be due to inorganic solids. RCRA metals were precipitated by increasing the $\mathrm{pH}$ of the solution. 
E/H GROUNDWATER COMPOSITE STUDIES AUGUST 15, 1990, REVISION 0
PAGE 2 OF 16

WSRC-TR-90-336

Treating the composite with a strong acid ion exchanger removes cations in solution and replaces them with, in this study, sodium ion. Similarly, treating the composite with a chelating ion exchange resin exchanges polyvalent cations for sodium. A small column of a strong acid resin and another containing a chelating resin were used to process samples of the composite. The strong acid resin was not exhausted until approximately 300 column volumes of composite had been processed. The chelating resin did not behave satisfactorlly with this feed; tonic components were concentrated chromatographically on the column, giving concentration surges, greater than influent concentrations, in the effluent when breakthrough occurred. Both resins were eluted with $0.1 \mathrm{M}$ nitric acid. Elutions curves showed that 30 column volumes of the acid were insufficient for the complete regeneration of both resins. Elther more concentrated acid or larger elution volumes would be necessary to elute the resins.

\section{PH ADJUSTMENT STUDIES}

One liter samples of the $F / H$ composite solution were $p H$ adfusted to $6,7,7.5$, and 8 , respectively, using $0.1 \mathrm{M} \mathrm{NaOH}$. The original pH of the composite was 3.3. A glass electrode was standardized using a pH 7 buffer. Table 1 lists the concentration of ionic species in the composite before and after $\mathrm{pH}$ adjustment and filtration through a $0.45 \mu \mathrm{m}$ filter. Solids were allowed to air dry over night (approximately 12 hours) before weighing.

The anount of precipitate formed per liter is given in Table 2. When computed on a per galion basis, the expected mass of precipitate from each of the $\mathrm{pH}$ values would be $0.37 \mathrm{~g}$ at $\mathrm{pH} 6,0.081 \mathrm{~g}$ at $\mathrm{pH} 7,1.2 \mathrm{~g}$ at $\mathrm{ph} 7.5$, and $4.2 \mathrm{~g}$ at $\mathrm{pH} 8$.

The precipitation at $\mathrm{pH} 8$ was repeated because of the anomalously high precipitate mass for that sample relative to the others. Also, filtrate analyses could not account for the mass of the precipitate. One liter of composite was $\mathrm{pH}$ adjusted to 8.1 with $0.1 \mathrm{M} \mathrm{NaOH}$. The mixture was filtered using a weighed $0.45 \mu \mathrm{m}$ filter. After drying overnight, the precipitate and filter were weighed. Analyses of the feed composite and filtrate for this sample wese essentially identical to those for the earlier pH 8 adjustment study. The precipitate, which was stili noticeably damp, weighed $1.2130 \mathrm{~g}$. After drying in an oven at $100^{\circ} \mathrm{C}$ for two hours the weight of this solid had reached a constant welght of $0.1100 \mathrm{~g}$. Thus, about $91 \%$ of the welght of the precipltate was due to water. Filtration of one liter of $\mathrm{pH}$ adjusted composite using a $0.45 \mu \mathrm{m}$ filter required about 30 minutes. 
ل4

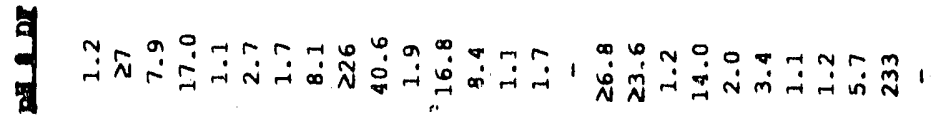

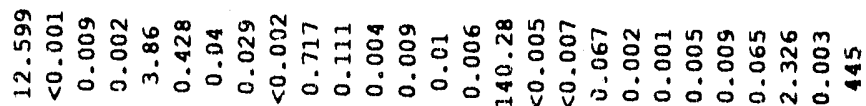

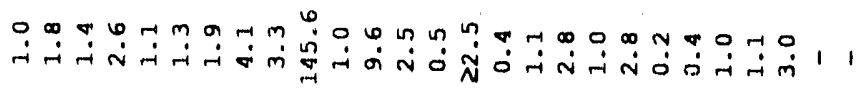

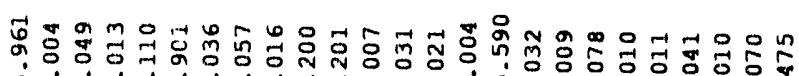

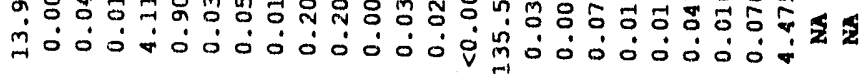

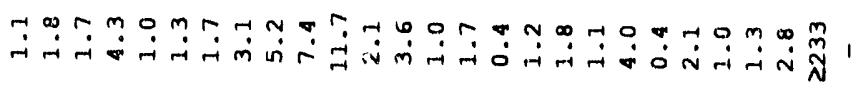

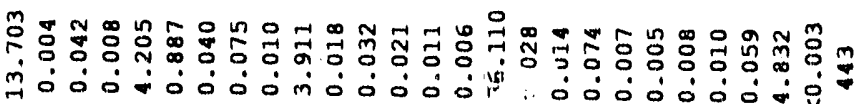

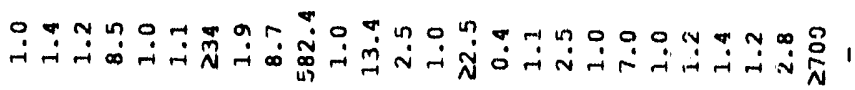

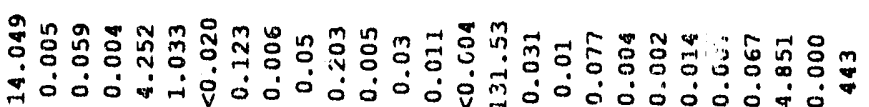

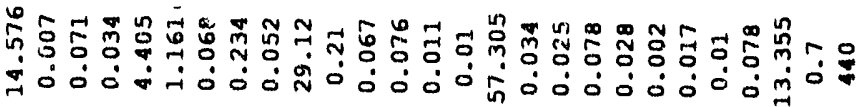


F/H GROUNDWATER COMPOSITE STUDIES AUGUST 15, 1990, REVISION O
PAGE 4 OF 16

WSRC-TR-90-336

Table 2. Mass of Procipitate Formed (Per Iiter) on $\mathrm{pH}$

Adjustment of $\mathrm{F} / \mathrm{H}$ Composite Groundwater

Clean filter

Filter + precipitate

precipitate
$\mathrm{pH} 6, \mathrm{~g} \mathrm{pH}, \mathrm{H}, \mathrm{g}$

69.1659

69.2638

0.0979
57.8681

57.8895

0.0214

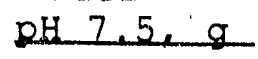

36.1573

36.4711

0.3138
$\mathrm{RH} 8, \mathrm{~g}$

68.7072

69.8085

1.1013

A titration curve was determined using $20 \mathrm{~mL}$ of the composite groundwater and $0.1069 \mathrm{M} \mathrm{NaOH}$. This is shown in Figure 1. To neutralize this groundwater, it will require $1.3 \mathrm{E}-2$ moles of NaOH per galion of groundwater. Since most of the neutralization is done on site using $50 z$ caustio $(19 \mathrm{M})$ solutions, it is of interest to note that one gallon of 50 \% caustic could neutralize $5.5 \mathrm{E}+3$ gallons of groundwater.

\section{Figure 1. F/H Composite Water Titration}

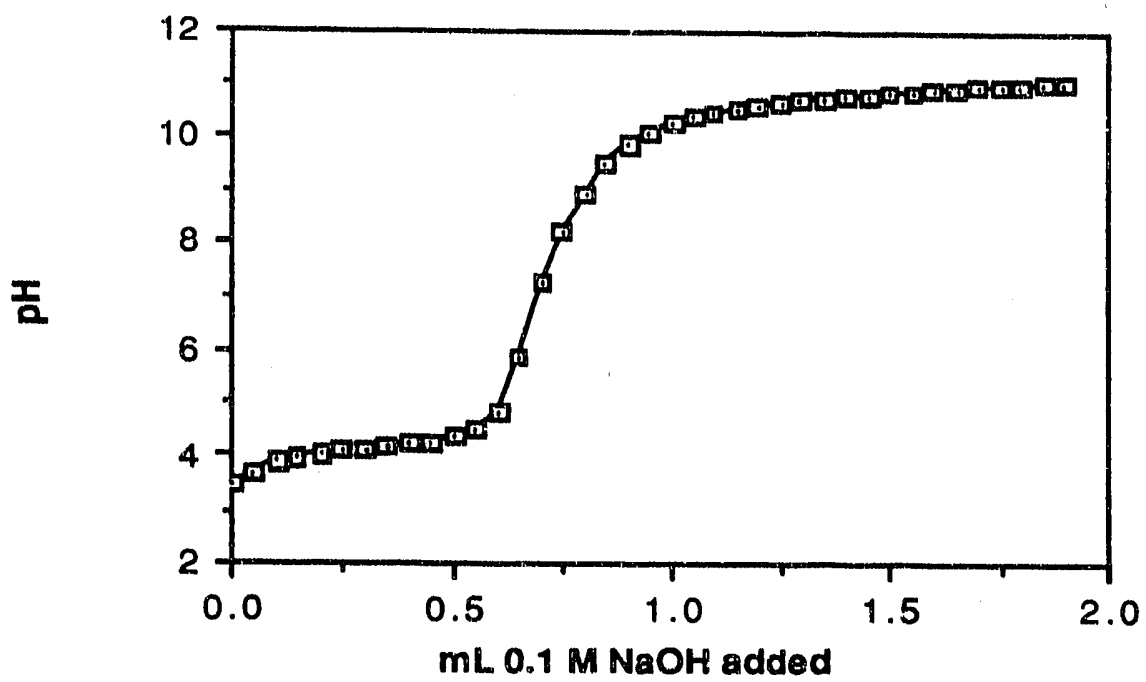

\section{PARTICLE STZE ANALYSIS OF PH ADJUSTED COMPOSITE PRECIPITATES}

Particle size distributions were studied using the Brinkman Model 2010 laser-based optical particle size analyzer. Table 3 lists the per cent of the total number of particles analyzed by the instrument in several particle diameter ranges. These data are all for scans made 
In the 0.5-150 $\mu \mathrm{m}$ region. Particles have been suspended by stirring with a magnetic stirrer inside the analytical cuvette. The size of particles did not appear to change significantly with pH. Previous studies on hydroxide precipitates have shown, however, that flocculated precipitates can be broken up by the stirring motion of the stirring star and the similarities may simply be a result of formation of a stable particle size within the cuvette.

Table 3. Number Distribution - Local Percentages of Total Recorded Particles

\begin{tabular}{|c|c|c|c|c|c|}
\hline Ranga & $\begin{array}{c}\text { Composite } \\
\text { Feed }\end{array}$ & DA 6 & DR 7 & 28.7 .5 & DA 8 \\
\hline $\begin{array}{l}0.0-1.0 \\
1.0=2.0 \\
2.0-3.0 \\
3.0=4.0 \\
4.0-5.0 \\
5.0=6.0 \\
6.0=7.0 \\
7.0=8.0 \\
8.0=9.0 \\
9.0=10.0 \\
10.0-20.0 \\
20.0-30.0 \\
30.0-40.0 \\
40.0-50.0\end{array}$ & $\begin{array}{r}27.68 \\
36.02 \\
14.60 \\
9.09 \\
5.78 \\
3.47 \\
1.32 \\
0.77 \\
0.38 \\
0.20 \\
0.62 \\
u .04 \\
0.01 \\
0.00\end{array}$ & $\begin{array}{r}42.57 \\
32.57 \\
11.62 \\
6.31 \\
3.69 \\
1.72 \\
0.75 \\
0.35 \\
0.19 \\
0.13 \\
0.09 \\
0.00 \\
0.01 \\
0.00\end{array}$ & $\begin{array}{r}21.82 \\
29.29 \\
19.21 \\
13.79 \\
7.99 \\
4.33 \\
1.66 \\
0.85 \\
0.33 \\
0.26 \\
0.44 \\
0.02 \\
0.00 \\
0.01\end{array}$ & $\begin{array}{r}25.26 \\
29.41 \\
17.98 \\
12.11 \\
7.05 \\
3.95 \\
1.87 \\
0.80 \\
0.46 \\
1.24 \\
0.75 \\
0.07 \\
0.04 \\
0.00\end{array}$ & $\begin{array}{r}30.34 \\
27.42 \\
16.25 \\
12.39 \\
7.30 \\
3.44 \\
1.72 \\
0.40 \\
0.26 \\
0.15 \\
0.26 \\
0.06 \\
0.02 \\
0.00\end{array}$ \\
\hline
\end{tabular}

\section{PRECIPITATION USING SULTIDE}

It was of interest to determine whether precipitation with sulfide would give better decontamination of heavy metals than precipitation with hydroxide. Therefore, a $1.0 \mathrm{M}$ Na2s solution was added to one liter of the composite groundwater sample until. precipitation occurred. This required $40 \mathrm{~mL}$ of solution. The precipitate was collected on a weighed $0.45 \mu \mathrm{m}$ filter, air dried for 12 hours, and weighed. Solids collected on the filter weighed $0.015 \mathrm{~g}$. ICP analysis of the filtrate is given in Table 1. Sulfide precipitation was slightly more efficient than hydroxide precipitation for $\mathrm{Ca}^{2+}$ and $\mathrm{Ba}^{2+}$ but not as efficient for other ions, particularly $\mathrm{Al}^{3+}$. The $\mathrm{pH}$ of the filtrate was 8.6 and this was higher than any of the hydroxide adjustment studies. The hydroxide concentration in the sulfide filtrate may have caused some of the metal hydroyides to begin to 
redissolve. Precipitation using $\mathrm{Na}_{2} \mathrm{~S}$ added more than 1.5 times the amount of sodium ion to the system than that added by precipitation at $\mathrm{pH} 8$ using $\mathrm{NaOH}$.

\section{RESIN SCREENING TESTS - Kd DETERMINATIONS}

Seven comnercially available resins were tested with F/H composite groundwater in batch experiments to determine distribution coefficients (Kd) for various lons in the composite. This screening test enabled the selection of one strong acid resin and one chelating resin for column experiments.

In the batch experiments, approximately $0.1 \mathrm{~g}$ of resin was shaken overnight with $15 \mathrm{~mL}$ of the composite. The system was presumed to be at equilibrium at that time. The equilibrium solution was then analyzed by ICPES and Kd's were calculated for each ion and each resin using the formula:

$$
\mathrm{Kd}=[(\mathrm{Co} / \mathrm{C}-1)(\mathrm{v} / \mathrm{g})]
$$

where Co is the initial concentration of the ion in the groundwater, $C$ is the equilibrium concentration of the ion, $v$ is the volume of solution $(15 \mathrm{~mL})$, and $\mathrm{g}$ is the dry weight of resin used. In general, the larger the $\mathrm{kd}$, the better the resin will remove the ion. Thus, resins with the highest Kd's overall for divalent cations were selected for column tests. Those resins were Dowex $50 \times 8$ and Chelex 100. The results from the $\mathrm{Kd}$ experiments are given in Table 4 . The chelating resins tested wer: Chelex 100, TP-207, CR-10, and CR-20. The strong acid resins tested were Dowex 50x8, PK-228, and PK-216.

\section{RESIN COLUMN TESTS}

\section{Dowex $50 \times 8$ Strong Acid Resin}

A two-mililiter column of Dowex $50 \times 8$ resin in the sodium form was prepared in deionized water. The mass of the resin column was 1.543 grams. The diameter of the column was 0.354 inches. A total of 800 $\mathrm{mL}$ (400 column volumes) of $\mathrm{F} / \mathrm{H}$ composite groundwater was processed downflow through the resin at a flow rate of $30 \mathrm{~mL} / \mathrm{hr}$. This represents 15 column volumes per hour and a linear flow rate of 2.9 $\mathrm{gpm} / \mathrm{ft}^{2}$. A more rapid flow rate was not possible because it would have required volumes of feed that the hood could not have accomodated. Effluent from the column was collected in $200-\mathrm{mL}$ fractions and analyzed for total uranium by U-Chemcheck and other 


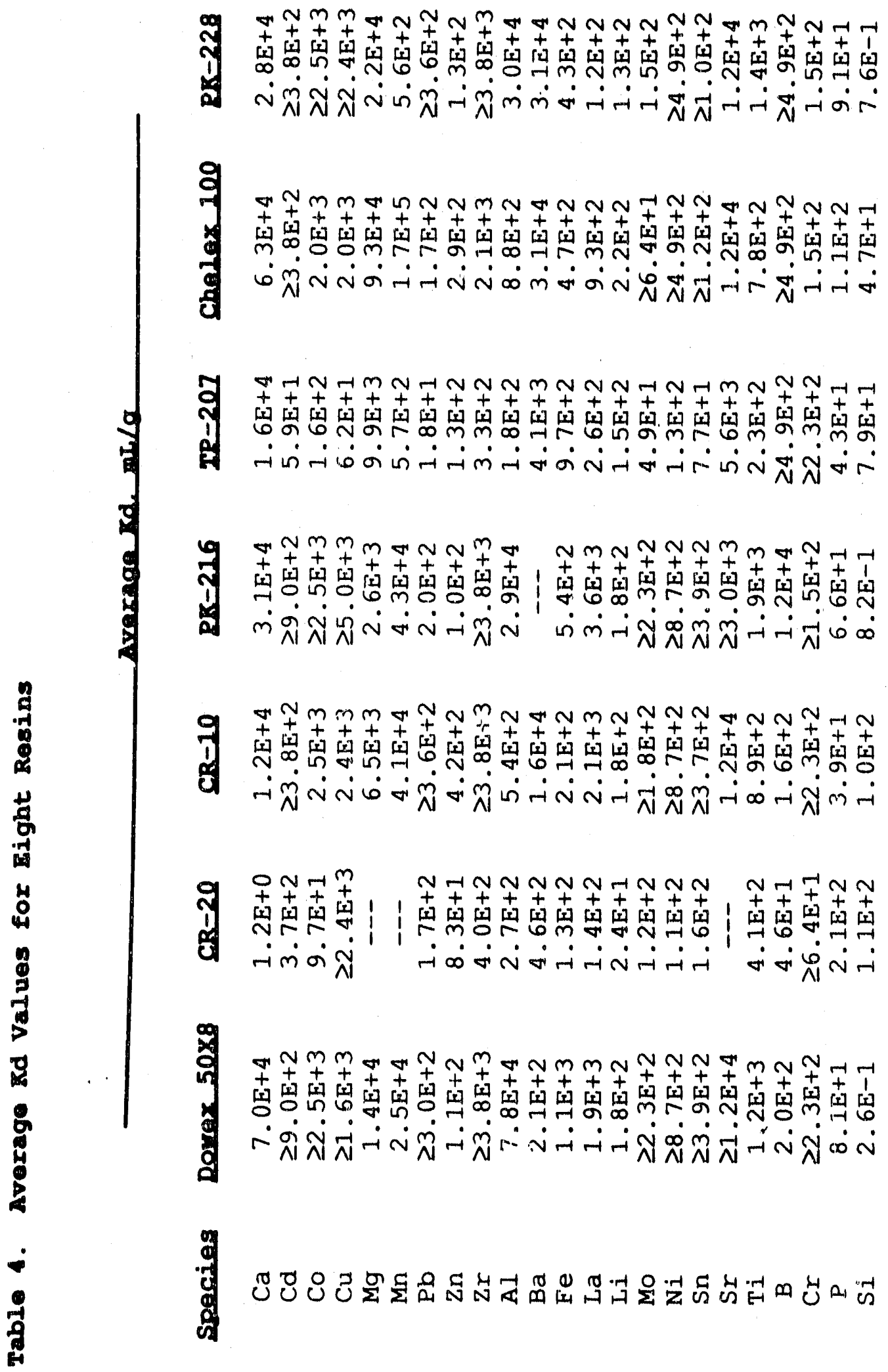


F/H GROUNDWATER COMPOSITE STUDIES

AUGUST 15, 1990, REVISION 0

PAGE 8 OF 16

WSRC-TR-90-336

cations by ICPES methods. The column appears to begin to experience breakthrough for most tons at about. 300 column volumes throughput. The results from the column run are given $\perp_{\mathrm{n}}$ Table 5 and are shown graphlcally for a representative ion, $\mathrm{Ca}^{2+}$, in Figure 2 . It is evident from Table 5 that the other lons begin to break through at about the same throughput.

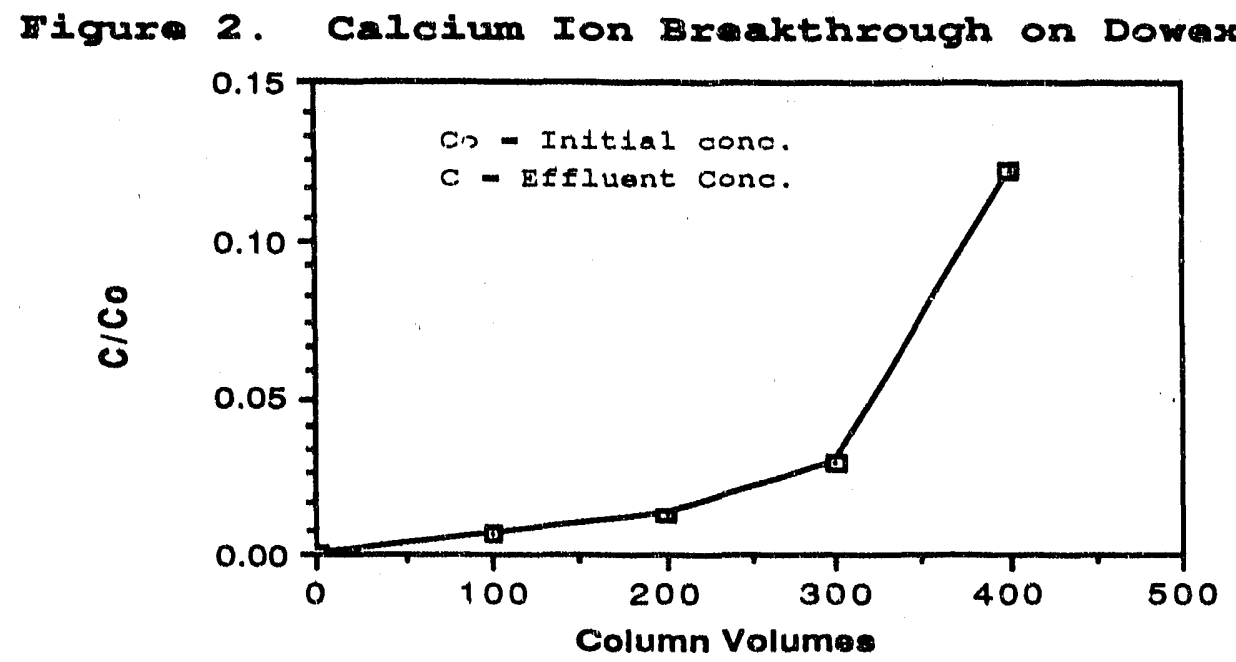

The column was then eluted downflow at $30 \mathrm{~mL} / \mathrm{hr}$ flow rate using $60 \mathrm{~mL}$ of $0.1 \mathrm{M} \mathrm{HNO}_{3}$. Six $10 \mathrm{~mL}$ elution fractions were collected and analyzed for $\mathrm{Hg}$ by atomic absorption, total $U$ by Chemcheck, and cations by ICPES. The results of these analyses are fourd in Table 6 and are shown graphically in Flgure 3 for the sodium ion.

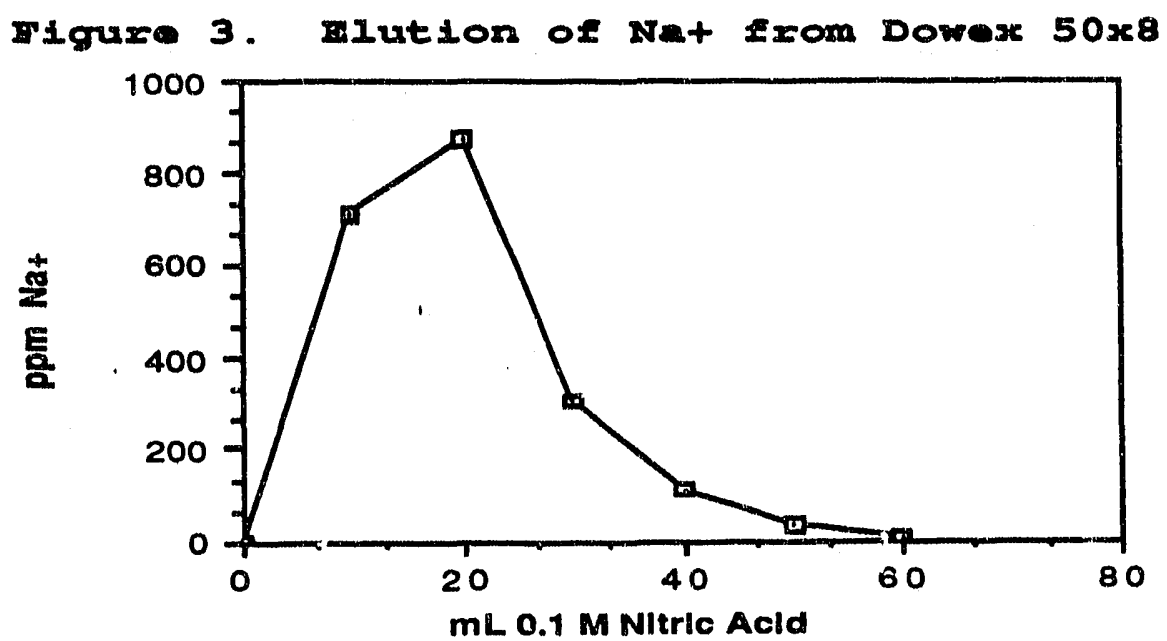


E/H GROUNDWATER COMPOSITE STUDIES AUGUST 15, 1990, REVISION $O$
PAGE 9 OF 16

WSRC-TR-90-336

Table 5. Dowex $50 \times 8$ Column Run Fffluent Concentrations

\begin{tabular}{|c|c|c|c|c|c|}
\hline \multirow[b]{2}{*}{ SPESIRS } & \multirow[b]{2}{*}{$\begin{array}{l}\text { Arernoge } \\
\text { Read._pgm }\end{array}$} & \multicolumn{4}{|c|}{ 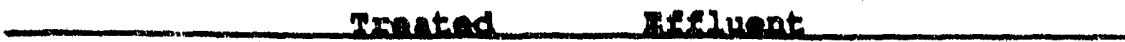 } \\
\hline & & $\begin{array}{c}\text { Liset } \\
100 \text { cy, }\end{array}$ & $\begin{array}{l}\text { Second } \\
200 \text { ar popp }\end{array}$ & $\begin{array}{l}\text { Thind } \\
200 \text { ar. prom }\end{array}$ & $\begin{array}{c}\text { Eouxtb } \\
100 \text { cre }\end{array}$ \\
\hline $\mathrm{Ca}$ & 14.58 & 0.101 & 0.19 & 0.43 & 1.80 \\
\hline$c d$ & 0.01 & $<0.001$ & $<0.001$ & $<0.001$ & 0.00 \\
\hline Co & 0.07 & $<0.004$ & $<0.004$ & $<0.004$ & 0.01 \\
\hline $\mathrm{Cu}$ & 0.03 & $<.003$ & 0.00 & 0.00 & 0.01 \\
\hline $\mathrm{Mg}$ & 4.41 & 0.015 & 0.05 & 0.20 & 0.97 \\
\hline $\mathrm{Mn}$ & 1.16 & 0.004 & 0.01 & 0.05 & 0.22 \\
\hline $\mathrm{Pb}$ & 0.07 & 0.057 & 0.02 & 0.04 & 0.02 \\
\hline $\mathrm{Zn}$ & 0.23 & 0.015 & 0.01 & 0.04 & 0.17 \\
\hline $\mathrm{zr}$ & 0.05 & 0.002 & $<0.002$ & 0.00 & 0.00 \\
\hline Al & 29.12 & 0.153 & 0.20 & 0.49 & 1.05 \\
\hline $\mathrm{Ba}$ & 0.21 & 0.003 & 0.00 & 0.01 & 0.01 \\
\hline Fe & 0.07 & 0.009 & 0.01 & 0.01 & 0.01 \\
\hline La & 0.08 & 0.003 & 0.00 & 0.01 & $<0.003$ \\
\hline LI & 0.01 & 0.003 & 0.01 & 0.01 & 0.02 \\
\hline Mo & 0.01 & $<0.004$ & 0.01 & $<0.004$ & $<0.004$ \\
\hline $\mathrm{N} \pm$ & 0.03 & 0.005 & 0.01 & 0.01 & 0.01 \\
\hline $\mathrm{sn}$ & 0.03 & 0.007 & 0.01 & $<0.007$ & 0.02 \\
\hline $\mathrm{sr}$ & 0.08 & 0.001 & 0.00 & 0.00 & 0.01 \\
\hline$T 1$ & 0.03 & 0.002 & 0.00 & 0.00 & 0.00 \\
\hline $\mathrm{v}$ & 0.00 & 0.001 & 0.00 & 0.00 & 0.00 \\
\hline$B$ & 0.02 & 0.153 & 0.18 & 0.20 & 0.23 \\
\hline $\mathrm{Cr}$ & 0.01 & 0.004 & 0.01 & $<0.004$ & $<0.004$ \\
\hline $\mathrm{P}$ & 0.08 & 0.033 & 0.04 & 0.03 & 0.03 \\
\hline S1 & 13.36 & 14.397 & 14.245 & 13.96 & 14.72 \\
\hline$U$ & 0.7 & $<0.01$ & $<0.01$ & 0.020 & 0.090 \\
\hline $\mathrm{Hg}$ & $<0.01$ & $<0.01$ & $<0.01$ & $<0.01$ & $<0.01$ \\
\hline
\end{tabular}




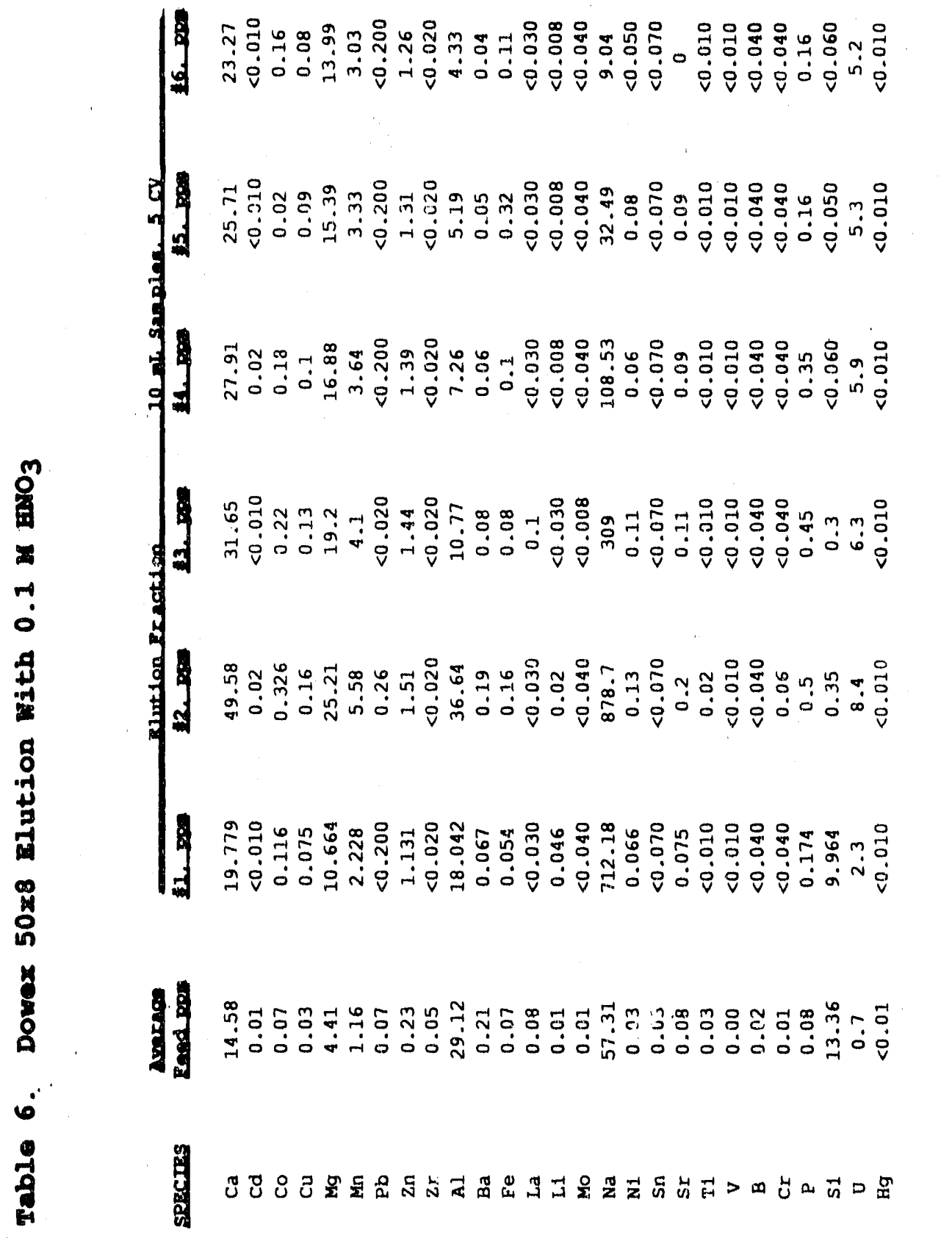


It is apparent from Table 6 that, although the monovalent ions, such as $\mathrm{Na}^{+}$, elute well in $0.1 \mathrm{M} \mathrm{HNO}_{3}$, the polyvalent ions, for example $\mathrm{Al}^{3+}, \mathrm{UO}_{2}{ }^{2+}$, and $\mathrm{Mn}^{2+}$, do not.

\section{Chelex 100 Chelating Resin}

A two-milliliter column of chelex 100 resin in the sodium form was prepared in deionized water. The mass of the resin column was 0.978 grams. The diameter of the column was 0.354 inches. A total of 1600 $\mathrm{mL}(800$ columa volumes) of $\mathrm{F} / \mathrm{H}$ composite groundwater was processed downfjow through the resin at a flow rate of $30 \mathrm{~mL} / \mathrm{hr}$. This represents 15 column volumes per hour and a linear flow rate of 2.9 $\mathrm{gpm} / \mathrm{ft}^{2}$. Once again, a more rapld flow rate was not possible because it would have required volumes of feed that the hood could not have accomodated. Effluent from the column was collected in 200-mI fractions and analyzed for total uranium and cations by ICPES and U-Chemcheck methods. The results from the column run are given in Table 7 and are shown graphicaliy in Figure 4 for $\mathrm{Ca}^{2}+$, representative ion.

\section{Figure 4. Calcium Ion Breakthrough on Chelex 100}

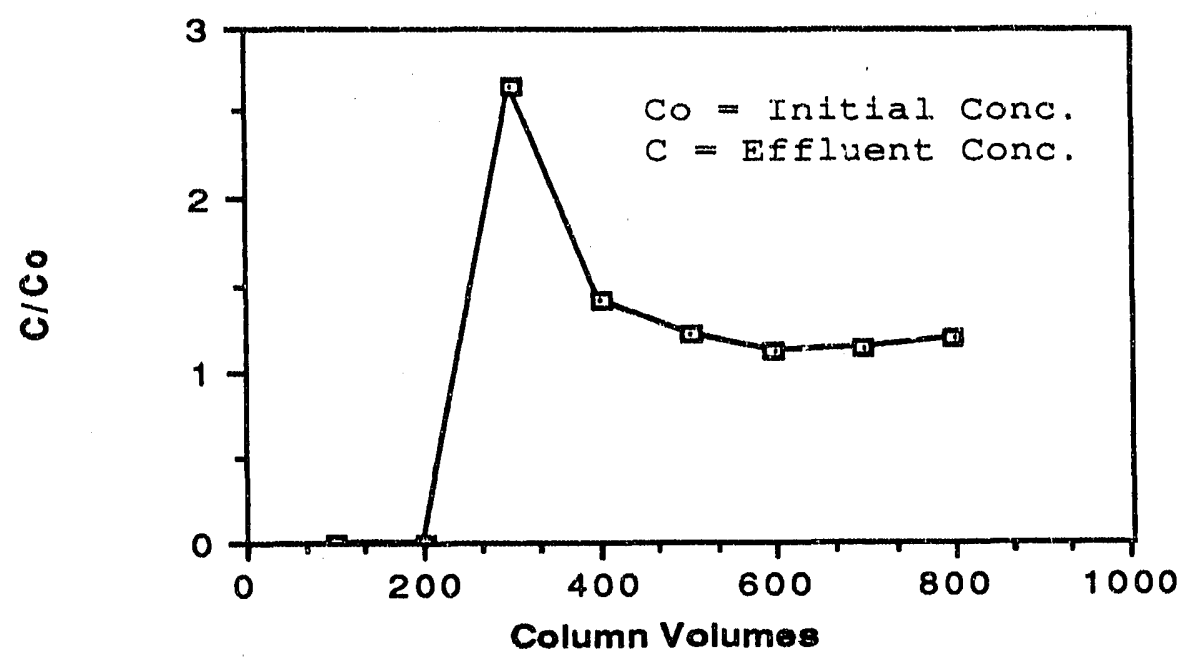

In addition to early breakthrough, the polyvalent ions appear to be concentrating in chromatographic bands before breaking through since they emerge from the column in much higher concentrations than in the feed. A chelating resin does not give good decontamination with this groundwater.

The column was then eluted downflow at $30 \mathrm{~mL} / \mathrm{hr}$ flow rate using $60 \mathrm{~mL}$ of $0.1 \mathrm{MHNO}_{3}$. Six 10-mL elution fractions were collected and analyzed 


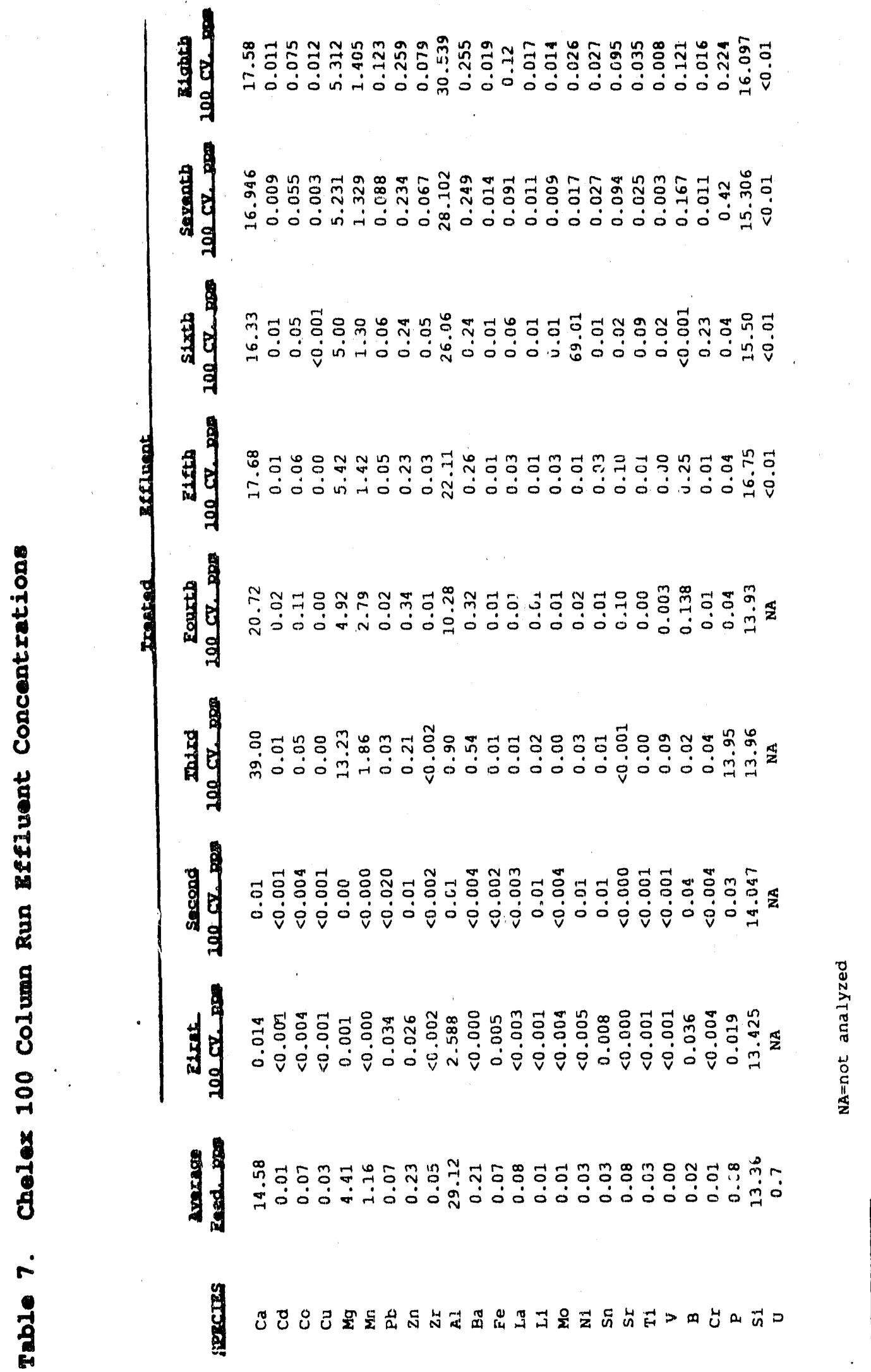


for $\mathrm{Hg}$ by atomic absorption, total $U$ by Chemcheck, and cations by ICPES. The results of these analyses are found in Tarle 8 and are shown graphically in Flgure 5 for the sodium ion. The resin does not elute efficiently with acld of this concentracion.

\section{Figure 5. Elution of Nat from Chelex 100}

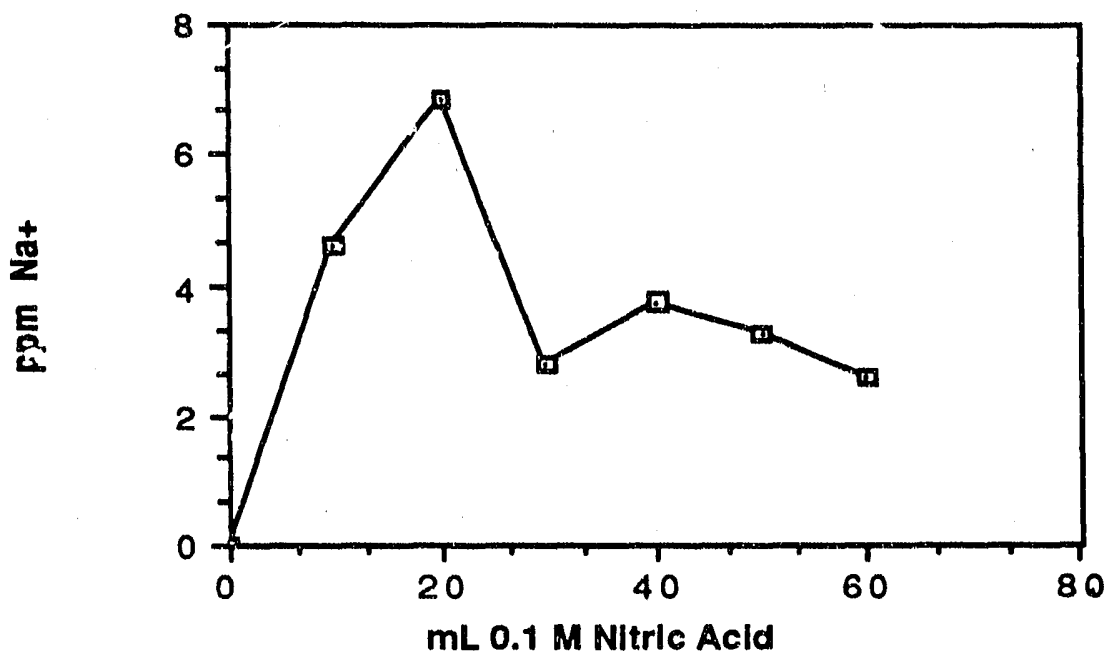

\section{DISCUSSION}

Precipltation by $\mathrm{pH}$ adjustment to values from 6-8 effect formation of few solids. Approximately $3.4 \mathrm{E}-3$ moles of $\mathrm{NaOH}$ per liter of groundwater (1.3 E-2 moles/gaj.lon) were required to raise the $\mathrm{pH}$ to 8 . The hydroxide precipitates are gelatinous in nature and are not easily filtered through a $0.45 \mu \mathrm{m}$ filter. Although the mass of precipitate produced increased on going from $\mathrm{pH} 6$ to 8 , it was demonstrated, by heating to dryness in an oven, that the increase was due to the mass of water that had been incorporated in the gel and not the mass of salts precipitated. Since filtration was very slow, alternative separation methods, such as centrifugation or decantation, should be studied. The properties of the precipitate would indicate that it will require dewatering after separation.

Treatment of the groundwater using sodium sulfide does effect precipitation as well as $\mathrm{pH}$ elevation of the solution. There are several arguments against the use of sulfide as a precipitating agent for this groundwater which must be considered. The final $\mathrm{pH}_{\text {, }}$ at which precipitation took place, was 8.55 , slightly above the drinking water maximum of 8.5. The concentrations of $\mathrm{Cd}^{2+}, \mathrm{Pb}^{2+}$, and total chromium in solution after sulfide precipitation are essentially the same or greater as those when $\mathrm{NaOH}$ was used as a precipitating agent, 
F/H GROUNDWATER COMPOSITE STUDIES

AUGUST 15, 1990, REVISION $O$

PAGE 14 OF 16

WSRC-TR-90-336

Table 8. Chezox 100 Elution With $0.1 \mathrm{M}$ mNO $_{3}$

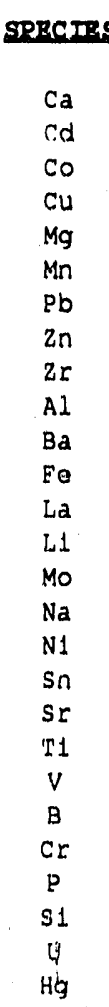

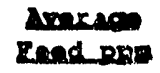

14.58

0.01

0.07

0.03

4.41

1.16

0.07

0.23

0.05

29.12

0.21

0.07

0.08

0.0 .1

0.01

57.31

0.03

0.03

0.08

0.0 .3

0.00

0.02

0.01

0.08

13.36

0.7

$<0.01$

\begin{tabular}{cc}
\hline 1.800 & 2.06 \\
3.62 & 0.06 \\
0.066 & 1.26 \\
0.955 & 0.05 \\
0.066 & 0.51 \\
0.066 & 0.19 \\
0.522 & 1.15 \\
1.45 & 3.76 \\
2.4 & 0.80 \\
0.86 & 686.60 \\
667.4 & 0.04 \\
0.098 & 0.06 \\
0.08 & 1.26 \\
1.26 & 0.01 \\
0.028 & 0.28 \\
0.21 & 6.86 \\
4.58 & 0.94 \\
0.39 & 0.45 \\
0.42 & 0.02 \\
0.055 & 0.62 \\
0.55 & 0.02 \\
0.022 & $<0.040$ \\
$<0.040$ & $<0.040$ \\
0.64 & 0.62 \\
0.47 & 1.80 \\
2.46 & 0.49 \\
$<0.01$ & $<0.01$ \\
$<0.01$ &
\end{tabular}

\begin{tabular}{|c|c|}
\hline 12 p pom & A. 000 \\
\hline 0.72 & 0.93 \\
\hline 0.07 & 0.03 \\
\hline 1.24 & 0.59 \\
\hline 0.56 & 1.34 \\
\hline 0.14 & 193.00 \\
\hline 0.06 & 0.57 \\
\hline 2.27 & 1.61 \\
\hline 3.90 & 3.98 \\
\hline 1.09 & 0.78 \\
\hline 709.80 & 462.65 \\
\hline 0.04 & 0.01 \\
\hline 0.22 & 0.41 \\
\hline 1.96 & 1.70 \\
\hline 0.03 & $<0.008$ \\
\hline 0.26 & 0.15 \\
\hline 2.83 & 3.74 \\
\hline 1.90 & 1.17 \\
\hline 0.59 & 2.25 \\
\hline 0.02 & 0.01 \\
\hline 0.87 & 0.63 \\
\hline 0.06 & 0.01 \\
\hline$<0.040$ & $<0.040$ \\
\hline 0.08 & 0.07 \\
\hline 1.68 & 1.68 \\
\hline 1.68 & 0.63 \\
\hline 6.9 & 11.9 \\
\hline$<0.01$ & $<0.01$ \\
\hline
\end{tabular}

C._.
0.74
$<0.010$
$<0.040$
0.50
0.15
0.04
$<0.200$
1.93
$<0.020$
18.27
$<0.004$
0.25
0.06
$<0.008$
$<0.040$
2.60
$<0.050$
$<0.070$
0.00
$<0.010$
$<0.010$
$<0.040$
$<0.040$
0.17
0.31
10.2
$<0.9:$

6. 160

0.86

0.02

$<0.040$

0.88

0.18

0.0

0.55

2.02

0.13

78.94

0.01

0.21

0.36

$<0.008$

0.07

3.29

0.07

0.09

0.01

0.10

$<0.010$

$<0.040$

$<0.040$

0.39

0.51

13.4

$<0.01$
0.74

$<0.010$

0.50

0.15

0.04

1.93

$<0.020$

18.27

0.25

0.06

$<0.008$

2.60

$<0.050$

$<0.010$

$<0.010$

$<0.040$

0.17

10.2

<0. : :

indicating no significant benefit in heavy metal decontamination when using sulfide. Addition of $\mathrm{Na}_{2} \mathrm{~S}$ increased the sodium ion concentration in treated effluent much more ( $>1.5$ times) than treatment with NaOH. The ultimate total sodium ion concentration in treated liquid may be a consideration. Finally, although the equilibrium concentration of $\mathrm{H}_{2} \mathrm{~S}$ in treated groundwater will be below the allowable drinking water concentration of $2 \mathrm{ppb}^{1}$, reinjection to a system that is at $\mathrm{pH} 3-4$ will temporarily convert all avallable sulfide in the treated solutions to $\mathrm{H}_{2} \mathrm{~S}$ in concentrations in excess of that $2 \mathrm{ppb}$ limit.

Processing composite groundwater through a strong acid resin such as Dowex $50 \times 8$ will remove all cationic species except hydrogen ion. Approximately 300 column volumes of feed were processec before breathrough was apparent. Elution of the column with 30 column 
F/H GROUNDWATER COMPOSITE STUDIES

AUGUST 15, 1990, REVISION 0

PAGE 15 OE 16

WSRC-TR*90-336

volumes of $0.1 \mathrm{M} \mathrm{HNO}_{3}$ was not efficient. Further elution studies should be made using more concentrated acid in order to optimize the complete regeneration of the column.

Chelex 100, a complexing ion exchange resin, did not perform well with the composite groundwater feed. The presence of many cation specles resulted in a pronounced multicomponent effect 2,3 where in 1ons, once sorbed, concentrated in chromatographic bands before breaking though. Initial breakthrough concentrations of each ion were greater than feed concentrations. Elution of the saturated column with 30 column volumes of $0.1 \mathrm{M} \mathrm{HNO}_{3}$ was not sufficient to completely regenerate the resin. If a chelating resin is to be considered for decontamination of this groundwater, more studies, including $\mathrm{pH}$ adjustment of the feed before ion exchange and different acid concentrations for elution, will have to be done.

\section{QUALITY ASSURANCE}

Data pertaining to this report can be found in WSRC-NB-89-106 on pages 92-110. The notebook is maintained in room B-132 of 773-A.

Chemical and radiochemical analyses were parformed by Analytical Development section (ADS) according to the ADS QA standards for "Routine Customer Assisted" analyses. The various techniques and methods are listed below:

Method Number

ADS -242.0

ADS -2306

ADS -2408

ADS -2503

ADS -2506

ADS -2201

ADS -2405

DPSOP 82-11
Procedure Titie

Gamma Sample Preparation and Analysis Analysis of solutions by Ion Chromatograph Tritium Extraction for Liquid Scintillation Analysis

Cold Vapor Atomic Absorption for $\mathrm{Hg}$

Direct Elemental analysis by ICP-AES

OIC-700 Total Carbon Analyzer

Alpha and Beta Plate Making Direct Mount and Count IP\#89331 Rev 0 11/89 U-Chemcheck, Analytical Laboratorles Separations Control Procedures

Particle size analyses were performed on a Brinkman Model 2010 laser-based computerized system for measuring particle size distributions. The system is self-calibrating but is also checked against a standard sample of $10 \mu \mathrm{m}$ polyethylene spheres purchased from NASA (National Aeronautics and Space Administration) by ADS. The standard is maintained by $A$. Jurgensen of ADS. 
F/H GROUNDWATER COMPOSITE STUDIES

AUGUST 15, 1990, KLVISION 0

PAGE 16 OF 16

WSRC-TR-90-336

Ar Orion Model $701 \mathrm{~A}$ digltal tonanalyzer equipped with a glass electrode was standardized using $\mathrm{pH} 4,7$, and 10 buffer solutions purchased from stores. Temperature corrections were made based on a calibrated thermometer, $\mathrm{BB}-1$, maintained in $\mathrm{B}-127$ of $773-\mathrm{A}$.

\section{REFERENCES}

1. "Quality Criterla for Water", U.S. Environmental Protection Agency, Washington, D.C.; pp. 213-215.

2. HELFEERICH, F., and KLEIN, G., Multicomponent Chromatography, Theory of Interference, Marcel Dekkex, Inc., New York, New York, 1970 .

3. BIBLER, J.P., "Effects of Heavy Metals on Cation Exchange Proposed for the F/H Effluent Treatment Facility", DPST-86-521, June 20, 1986 .

4. BIBLER, J.P., "Technica.l Studies on CS Decon of the Organic Product Stream from the DWPE", WSRC-TR-90-295.

CC: W.L. Tamosaltis, 773-A

M.A.Ebra, 703-H

G.W. Becker, 703-H

K. Wierzbick1, 703-H

O.B. Wheat, 703-H

C.M. Lewis, 703-H

J.C. Guynn, 703-H

B.B. Looney, 773-42A

J.B. Gladden, 773-42A

R.H. Sentelle, CDC-North Augusta

D. Nix, CDC-North Augusta

R. Brandt, 703-A S. P. Surovehat, 703-A

G. Tiurmer 
ACTION ITEM

Action Inflator:

Meeting

Telephone Conversation

MAIL From IMD
Inspection

Other

(Explain)

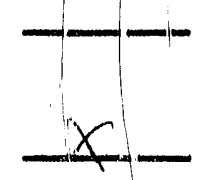

Date: $2 / 20 / 92$

Participants:

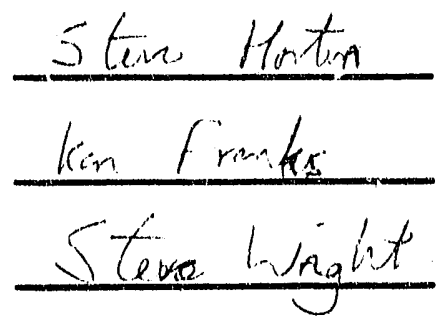

ACTION DESCRIPTOR

Action
From: ERD

Action

To:

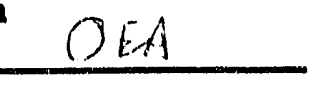

Due Date:

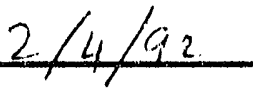

Person Responsible: Steve Hint mi

subject: $h$ here $-\pi n-90-336$

Action: Revinuthare Stine W. sign 

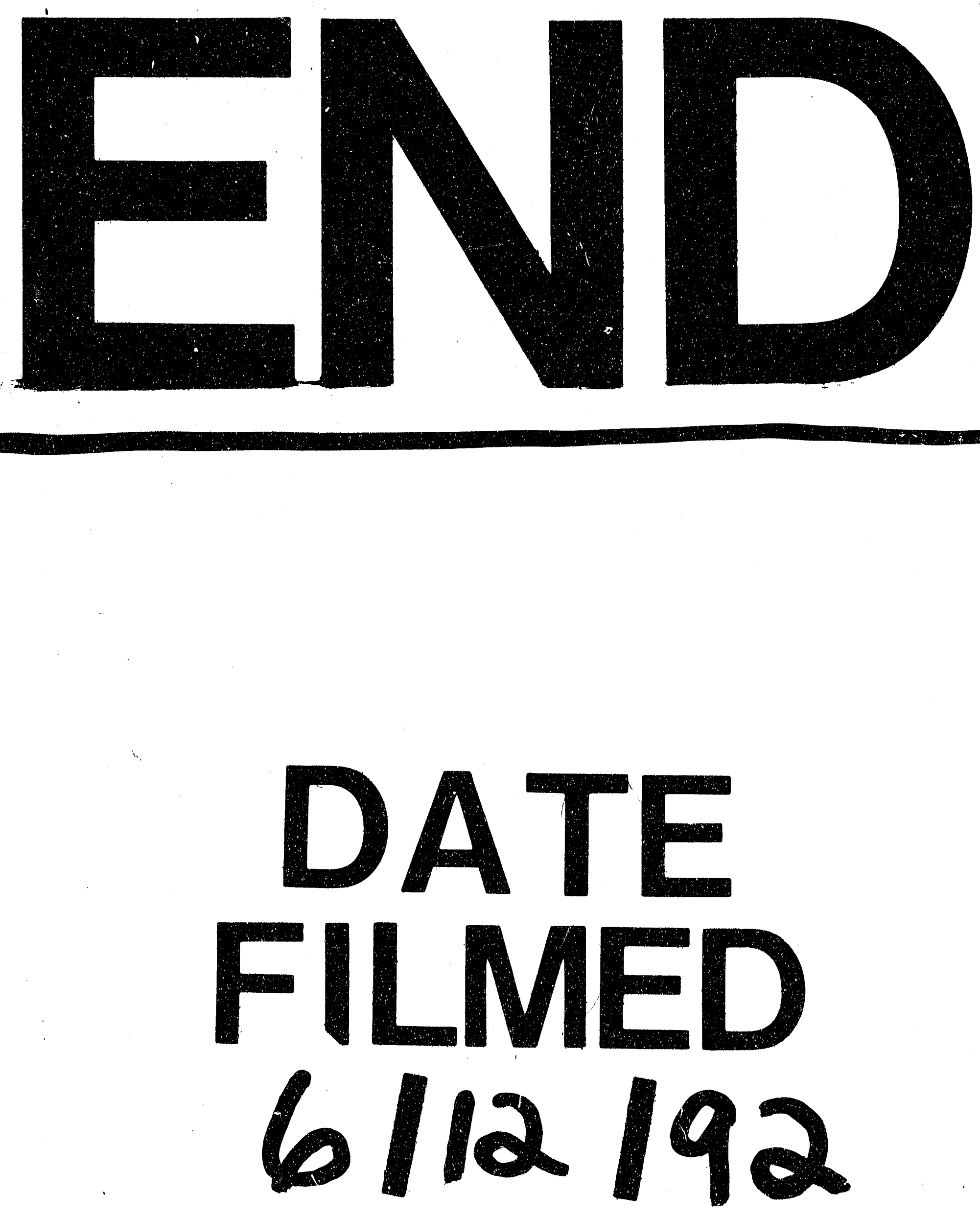


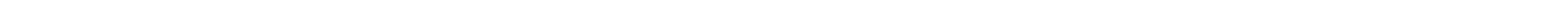

